\title{
ANÁLISE DO FORO ESPECIAL POR PRERROGATIVA DE FUNÇÃO NO JULGAMENTO DE CRIMES COMUNS E MODIFICAÇÕES GERADAS NA AÇÃO PENAL $937^{1}$
}

ANALYSIS OF THE SPECIAL FORUM BY PRERROGATIVE OF FUNCTION IN THE JUDGMENT OF COMMON CRIMES AND MODIFICATIONS GENERATED IN CRIMINAL ACTION 937

Júlio Dias TALIBERTI²

ISSUE DOI: $10.21207 / 2675-0104.2019 .882$

\begin{abstract}
RESUMO
O objetivo deste trabalho é analisar o foro especial por prerrogativa de função, no tocante ao julgamento de crimes comuns, de modo a entender o instituto e seus procedimentos, bem como compreender as modificações geradas na questão de ordem da ação penal 937. Para isso, faz-se um estudo da legislação história e vigente, bem como uma ampla pesquisa jurisprudencial, abordando discussões polêmicas e atuais sobre a prerrogativa de função. Deste modo, é possível compreender que a real intenção do foro especial não é proteger indiscriminadamente autoridades, mas sim evitar que estas sejam expostas aos azares dos julgamentos de juízes singulares e do inconsciente coletivo das ruas. A análise dos procedimentos da ação penal originária na prerrogativa examina todas as fases envolvidas no processo penal, desde a fase preparatória até a execução da decisão, permitindo entender os trâmites. Quanto às mudanças advindas da questão de ordem da ação penal 937 é possível entender como o instituto passará a funcionar, bem como verificar o ativismo judicial praticado pelo Supremo; que com a alteração, reduz, em muito, sua competência para o julgamento destas ações.
\end{abstract}

\footnotetext{
${ }^{1} \mathrm{O}$ presente artigo sintetiza a monografia de conclusão da pesquisa, realizada para o Programa Interno de Bolsas de Iniciação Científica (PIBIC 2018-2019) da Faculdade de Direito de Franca (FDF), Franca/SP.

${ }^{2}$ Discente da Faculdade de Direito de Franca (FDF), Franca/SP. Bolsista do Programa Interno de Bolsas de Iniciação Científica (PIBIC 2018-2019).
} 
Palavras-chave: Foro Privilegiado; Interferência do Judiciário; Ação Penal Originária.

\begin{abstract}
The objective of this paper is analyze the forum prerrogative, in relation to the common crimes judgment, in order to understand the institute and its procedures, as well as understand the modifications genereted in the matter of order of criminal action 937. For this, it was made a study of the historical and actual legislation, as well as a extensive jurisprudencial research, approaching controversial and current disscussion about the forum prerrogative. In this way, it is possible to understand that the real intention of the forum prerogative is not to protect indiscriminately, but rather, to prevent authorities from being subjected to the judgments of individual judges and the collective unconscious of the streets. The analyze of the original criminal action procedures scan all the stages involved in the criminal procedure, since the preparatory stage until the execution of the decision, allowing to understand that. About the changes arising from the matter of order criminal action 937, its possible to understand how the institute will work as verify the judicial activism practiced by the supreme; which, with the change greatly reduces your competence to judge these actions.
\end{abstract}

Keywords: Privileged Forum; Judiciary Interference; Original Criminal Action.

Os escândalos criminais, denúncias, investigações e prisões envolvendo figura dos três poderes, têm voltado os olhos do país e do mundo para o judiciário, gerando a necessidade de se discutir como funciona o julgamento destas através do foro especial por prerrogativa de função para crimes comuns, bem como seus procedimentos.

Ainda, em maio de 2018, durante o julgamento da ação penal 937, foi levantada questão de ordem pelo Ministro Barroso que gerou uma nova interpretação restritiva do foro por prerrogativa de função. Assim, importa entender como as mudanças advindas reformulam regras e procedimentos no foro especial.

Para tanto, o trabalho realiza um apanhado histórico sobre a prerrogativa nas constituições brasileira, apresentando motivos de sua existência e extensão, bem como analisa julgados para melhor compreender o instituto.

Ainda, faz uma análise de todas as fases envolvidas nos procedimentos da ação penal originária, enfrentando as principais controvérsias e polêmicas envolvendo a prerrogativa de função como o inquérito policial no STF, o princípio do duplo grau de jurisdição, a prisão em segunda instância e o ativismo judicial.

Por fim, o presente trabalho pretende contribuir para os atuais debates dissecando a prerrogativa de função nos crimes comuns, expondo 
seu funcionamento, seus novos contornos advindos da questão de ordem da ação penal 937 e as perspectivas das implicações que podem ocorrer.

\section{FORO ESPECIAL POR PRERROGATIVA DE FUNÇÃO: CONCEITO E HISTÓRICO CONSTITUCIONAL}

O Foro especial por prerrogativa de função é um mecanismo do sistema judiciário, no Brasil previsto pela Constituição Federal e pelas Constituições Estaduais, no qual a competência para julgar determinadas autoridades públicas, por crimes comuns ou de responsabilidade, é originalmente atribuída às instâncias superiores.

Estabelece, por exemplo, a Constituição Federal no art. 102, alínea "b", a competência do Supremo Tribunal Federal para julgar o Presidente da República nas infrações penais comuns por ele cometidas. A locução "infrações penais comuns" abarca desde contravenções penais até crimes dolosos contra vida, incluindo os delitos eleitorais.

O instituto é fixado ratione personae, isto é, em razão de uma característica circunstancial do indivíduo envolvido, v.g. estar na condição de deputado federal. Assim, idealiza a proteção do cargo e da instituição que representa, não da pessoa que o ocupa. Visa evitar que altas autoridades, figuras centrais do funcionamento da nação, sejam processadas indiscriminadamente e por qualquer juízo.

Esclarece Pontes de Miranda o motivo da prerrogativa ao chefe do executivo: "evitar se exponha o Presidente da República aos azares dos julgamentos de juízes singulares, talvez em momentos de lutas políticas e ódios vivos". 3

No mesmo sentido, o ex Presidente Fernando Collor, sobre o processo que levou a sua cassação, escreveu: "mas as [provocações] da vida pública, essas têm que ser suportadas com resignação e silêncio, especialmente quando insufladas pelas paixões e alimentas pelo fragor das ruas, insufladas pela cegueira das emoções."4

\footnotetext{
${ }^{3}$ PONTES DE MIRANDA, Francisco Cavalcanti. Comentários à Constituição de 1967. São Paulo: Revista dos Tribunais, 1968. T. V. p. 248-249.

${ }^{4}$ MELLO, Fernando Collor de. Réplica para a história: uma catarse. Brasília: Senado Federal, 2016. 254 
Seguindo essa linha de raciocínio, justifica-se a prerrogativa a determinadas autoridades para que não sejam indiscriminadamente processadas e não sejam julgadas pelo inconsciente coletivo, mas sim pelos fatos e normas que compõem o caso concreto. Sem o foro especial, um prefeito de um município pequeno, por exemplo, teria seu julgamento aos sabores do arbítrio do único juiz da cidade, que poderia ser influenciado pelo sentimentalismo do momento naquela comunidade.

Para entender a estrutura do foro especial no Brasil é preciso fazer uma evolução histórica do tratamento constitucional do instituto ao longo da história; começando pela Constituição de 1824, que introduzia o Poder Moderador e dava imunidade ao Imperador. O art. 99 da Carta estabelecia que "A Pessoa do Imperador é inviolável, e Sagrada: Elle não está sujeito a responsabilidade alguma." " . O Documento colocava o Chefe da Nação em uma posição intocável, além do alcance da justiça, mas também aboliu privilégios pessoais que não eram inerentes a cargos, mas sim a posições sociais.

Deste modo, determinava o inciso XVI do art. 179 da Constituição de 1824: "XVI. Ficam abolidos todos os Privilégios, que não forem essencial, e inteiramente ligados aos Cargos, por utilidade publica." ${ }^{\text {. }}$

Nesta mesma seara, a Constituição do Império, no inciso I do art. 47, atribuía ao Senado a competência para conhecer os delitos praticados pelos membros da Família Real, Ministros de Estado, Conselheiros de Estado, os próprios Senadores e os Deputados. Todavia, devia ser autorizado previamente pela Câmara dos Deputados, conforme o art. 38. ${ }^{7}$

Também em razão da função atribuía o art. 164, II, da mesma Carta, a competência do Supremo Tribunal de Justiça para conhecer os delitos e erros do ofício cometidos pelos seus próprios Ministros, os Magistrados dos Tribunais das Relações, os empregados do Corpo

\footnotetext{
${ }^{5}$ BRASIL. Constituição (1824). Constituição Política do Império do Brazil.Outorgada em 25 de março de $1824 . \quad$ Disponível em: <http://www.planalto.gov.br/ccivil_03/Constituicao/Constituicao24.htm>. Acesso em: 16 nov.2018. ${ }^{6}$ BRASIL. Constituição (1824). Constituição Política do Império do Brazil. Outorgada em 25 de março de $1824 . \quad$ Disponível em: <http://www.planalto.gov.br/ccivil_03/Constituicao/Constituicao24.htm>. Acesso em: 16 nov.2018. ${ }^{7}$ BRASIL. Constituição (1824). Constituição Política do Império do Brazil. Outorgada em 25 de março de $1824 . \quad$ Disponível em: <http://www.planalto.gov.br/ccivil_03/Constituicao/Constituicao24.htm>. Acesso em: 16 nov.2018.
} 
Diplomáticos e os Presidentes das Províncias ${ }^{8}$. A Igreja continuava gozando de privilégios, tendo os arcebispos e bispos prerrogativa de foro pelo mesmo Tribunal, segundo o art. $1 .^{\circ}$ do Decreto n. ${ }^{\circ} 609$, de 18 de agosto de $1851 .^{9}$

O início da fase Republicana e a promulgação da Constituição de 1891 representam um passo além na busca pelo fim dos privilégios. A própria Carta determina o fim do foro privilegiado ${ }^{10}$ no $§ 23$ do art. $72 \mathrm{e}$ determina a responsabilidade dos agentes públicos. É a primeira vez da história brasileira que o Chefe da Nação pode ser julgado, atribuindo ao Supremo Tribunal Federal a competência para os crimes comuns e ao Senado pelos crimes de responsabilidade.

Nota-se que o Documento de 1891 buscou delimitar apenas às autoridades máximas da vida republicana a prerrogativa de função, sendo: o Presidente da República, os Ministros de Estado e os ministros diplomáticos.

A Constituição de 1934 amplia o rol de funções com prerrogativa de julgamento. A Corte Suprema passa a julgar nos crimes comuns: seus próprios pares, o Presidente, Ministros de Estado, o Procurador Geral da República, os Juízes dos Tribunais federais, das Cortes de Apelação, os Ministros do Tribunal de Contas, Embaixadores e Ministros Diplomáticos ${ }^{11}$. Também cria um Tribunal Especial que sorteia três Ministros da Suprema Corte, três Deputados e três Senadores para julgar o Presidente e os Ministros de Estado nos crimes de responsabilidade. ${ }^{12}$

A Constituição de 1937, por seu caráter autoritário, volta a imunizar o Chefe da Nação, impedindo que este seja responsabilizado por atos estranhos ao exercício da função presidencial ${ }^{13}$. Apenas seria julgado

\footnotetext{
${ }^{8}$ BRASIL. Constituição (1824). Constituição Política do Império do Brazil. Outorgada em 25 de março de $1824 . \quad$ Disponível em: <http://www.planalto.gov.br/ccivil_03/Constituicao/Constituicao24.htm>. Acesso em: 16 nov.2018. ${ }^{9}$ BRASIL. Colecção de Leis do Império do Brasil. Rio de Janeiro, 1851. Tomo 12. Parte 1. Secção 1. ${ }^{10}$ BRASIL. Constituição (1891). Constituição da República dos Estados Unidos do Brasil. Promulgada em 24 de fevereiro de 1891. Disponível em: <http://www.planalto.gov.br/ccivil_03/Constituicao /Constituicao91.htm>. Acesso em: 16 nov.2018. 11 BRASIL. Constituição (1934). Constituição da República dos Estados Unidos do Brasil. Promulgada em 16 de julho de 1934. Art. 76, 1º, alínea A e B. Disponível em: <http://www.planalto.gov.br/ccivil_03/Constituicao/Constituicao34.htm>. Acesso em: 16 nov. 2018. 12 BRASIL. Constituição (1934). Constituição da República dos Estados Unidos do Brasil. Promulgada em 16 de julho de 1934. Art. 58. Disponível em: <http://www.planalto.gov.br/ccivil_03/Constituicao/Constituicao34.htm>. Acesso em: 16 nov. 2018. 13 BRASIL. Constituição (1937). Constituição dos Estados Unidos do Brasil. Outorgada pelo Presidente Getúlio Vargas em 10 de novembro de 1937. Art. 87. Disponível em: <http://www.planalto.gov.br/ccivil_03/Constituicao/Constituicao37.htm>. Acesso em: 16 nov. 2018
} 
por crimes de responsabilidade perante o Conselho Federal, que voltaria a ser chamado de Senado na Constituição de 1946, após declarada por dois terços de votos da Câmara dos Deputados a procedência da ação; da mesma forma seriam julgados os Ministros de Estado por crimes de responsabilidade. Nos crimes comuns mantiveram-se praticamente as mesmas prerrogativas da Constituição de 1934, sendo julgados pelo Supremo Tribunal Federal ${ }^{14}$.

A redemocratização brasileira e a promulgação da Constituição de 1946 voltam a trazer contornos mais democráticos ao exercício da justiça, o Presidente da República volta a ser julgado pelos seus crimes comuns perante o Supremo Tribunal Federal, após deliberação da Câmara dos Deputados ${ }^{15}$. Mas, pela primeira vez, a Carta Federal permite que as Constituições Estaduais estabeleçam competências originárias na organização de suas justiças ${ }^{16}$ e determina aos Tribunais de Justiça o julgamento dos juízes de inferior instância nos crimes comuns e de responsabilidade ${ }^{17}$.

A Constituição de 1967 é marcada por mudanças significativas impostas pelos Atos Institucionais e pela Emenda Constitucional n. ${ }^{\circ} 1 \mathrm{de}$ 1969. A priori a Carta previa a prerrogativa de função ${ }^{18}$, todavia, o Ato Institucional n. 5, de 1968, no inciso I do art. 5. ${ }^{\circ}$ determinava a "cessação de privilégio de foro por prerrogativa de função" que durou até a promulgação da referida Emenda Constitucional, com a previsão da competência originária do Supremo Tribunal Federal para julga

\footnotetext{
14 BRASIL. Constituição (1937). Constituição dos Estados Unidos do Brasil. Outorgada pelo Presidente Getúlio Vargas em 10 de novembro de 1937. Art. 101, inciso I, alíneas A e B. Disponível em: 〈http://www.planalto.gov.br/ccivil_03/Constituicao/Constituicao37.htm>. Acesso em: 16 nov. 2018

${ }^{15}$ BRASIL. Constituição (1946). Constituição dos Estados Unidos do Brasil. Promulgada em 18 de setembro de 1946.2 Art. 88.20 Disponível <http://www.planalto.gov.br/ccivil_03/Constituicao/Constituicao46.htm>. Acesso em: 17 nov. 2018.

${ }^{16}$ BRASIL. Constituição (1946). Constituição dos Estados Unidos do Brasil. Promulgada em 18 de setembro de 1946. Art. 124. Disponível em: <http://www.planalto.gov.br/ccivil_03/Constituicao/Constituicao46.htm>. Acesso em: 17 nov. 2018. ${ }^{17}$ BRASIL. Constituição (1946). Constituição dos Estados Unidos do Brasil. Promulgada em 18 de setembro de 1946. Art. 124, inciso IX. Disponível em: <http://www.planalto.gov.br/ccivil_03/Constituicao/Constituicao46.htm>. Acesso em: 17 nov. 2018. ${ }^{18}$ BRASIL. Constituição (1967). Constituição da República Federativa do Brasil. Promulgada em 24 de janeiro de $1967 . \quad$ Disponível em: <http://www.planalto.gov.br/ccivil_03/Constituicao/Constituicao67.htm>. Acesso em: 17 de nov. 2018.
} 
determinadas autoridades, incluindo pela primeira vez o Vice-Presidente, os Deputados e Senadores no rol. ${ }^{19}$

A Constituição de 1988 é a que mais abrange cargos na história do Brasil, junto com a permissividade para que a estaduais também estabeleçam, perfazem em torno de 54.990 autoridades ${ }^{20}$. Para compreender os motivos que levaram o constitucionalista de 1988 a garantir a prerrogativa de função para tantas autoridades na própria Carta é necessário vislumbrar que o país acabava de passar por 21 anos de Ditadura Militar, no qual a segurança jurídica era mitigada.

Assim, entendeu-se importante que as figuras centrais da administração pública nas três esferas do poder tivessem a garantia de um processo seguro, justo e eficaz, de modo a assegurar que a vontade emanada pelo povo através do voto não se submeteria às inclinações de governantes autoritários ou de juízes singulares.

\section{PROCEDIMENTOS DA AÇÃO PENAL ORIGINÁRIA NA PRERROGATIVA DE FUNÇÃO}

Diante do fato de determinadas autoridades, em razão da função exercida, terem seus crimes comuns julgados originalmente pelos tribunais, é preciso estudar os procedimentos e fases envolvidas na ação penal originária; assim, podem ser identificadas seis fases, são elas: fase preparatória, postulatória, probatória, decisória, recursal e executória ${ }^{21}$.

Fase preparatória é a pré-processual que vai desde noticia criminis até o oferecimento da denúncia. Embora o inquérito policial não seja a única forma de identificação da fase preparatória, este merece especiais considerações em se tratando do foro especial.

O Regimento Interno do Supremo Tribunal Federal ${ }^{22}$ determina que investigações de autoridades detentoras de foro especial, perante a

\footnotetext{
19 BRASIL. Ato Institucional n. ${ }^{\circ}$, de 13 de novembro de 1968. Disponível em: <http://www.planalto.gov.br/ccivil_03/AIT/ait-05-68.htm>. Acesso em: 18 nov. 2018.

${ }^{20}$ CAVAlCANTE FILHO, J. T. \& LIMA, F. R. Foro, Prerrogativa e Privilégio (Parte 1): Quais e quantas autoridades têm foro no Brasil? Brasília: Núcleo de Estudos e Pesquisas/ CONLEG/Senado, 2017

${ }^{21}$ CORRÊA, Plínio. Ação penal originária: Procedimentos. Porto Alegre: Síntese, 2001. p. 66.

${ }^{22}$ BRASIL. Regimento Interno. Supremo Tribunal Federal. Brasília, 2018, Art. 21, Inciso XV. Disponível 
referida corte, só poderão ter início ou prosseguimento com sua autorização, que assume um papel de supervisão jurisdicional direta, sob a justificativa de mitigação da garantia, uma vez que esta busca dar segurança e estabilidade às funções.

Assim, no curso de uma investigação, a autoridade policial, ao se deparar com indícios de participação de pessoa com prerrogativa de foro perante o Supremo Tribunal Federal, deverá remeter os autos do inquérito ao referido Tribunal. De qualquer modo, o relator do caso determinará pela autorização para iniciar ou prosseguir o inquérito ou procederá seu arquivamento. $^{23}$

Autorizada, a autoridade policial terá 60 dias para reunir os elementos necessários à conclusão da investigação ${ }^{24}$, prazo que poderá ser prorrogado a requerimento desta ou do Procurador Geral da República ${ }^{25}$. Após concluída, a peça informativa deverá ser apresentada, que será encaminhada pelo Relator ao Procurador Geral da República que poderá oferecer a denúncia ou requerer o arquivamento ${ }^{26}$.

Diferentemente do STF, o Superior Tribunal de Justiça tem decidido e reafirmado o entendimento de que é desnecessária a autorização judicial para investigar pessoas com foro privilegiado, tanto em casos de ação penal originária no STJ como nos Tribunais de Justiça, tendo em vista que a lei não excepciona a forma pela qual se procederá a investigação. Assim, deve-se aplicar a regra geral do Art. 5. ${ }^{\circ}$, inciso II, do Código de Processo Penal, que não requer prévia autorização judicial.

Dessa forma, o Ministro Jorge Mussi, em seu voto como relator do Agravo Regimental no Habeas Corpus n. ${ }^{\circ} 404.228$, quando suscitada a questão de necessidade de autorização para instauração do inquérito

$\langle$ http://www.stf.jus.br/arquivo/cms/legislacaoRegimentoInterno/anexo/RISTF_integral.pdf $>$. Acesso em: 21 nov. 2018.

${ }^{23}$ BRASIL. Regimento Interno. Supremo Tribunal Federal. Brasília, 2018, Art. 21, Inciso XV. Disponível em: <http://www.stf.jus.br/arquivo/cms/legislacaoRegimentoInterno/anexo/RISTF_integral.pdf $>$. Acesso em: 21 nov. 2018.

${ }^{24}$ BRASIL. Regimento Interno. Supremo Tribunal Federal. Brasília, 2018, Art. 230-C. Disponível em: 〈http://www.stf.jus.br/arquivo/cms/legislacaoRegimentoInterno/anexo/RISTF_integral.pdf>. Acesso em: 21 nov. 2018.

${ }^{25}$ BRASIL. Regimento Interno. Supremo Tribunal Federal. Brasília, 2018, Art. 230-C, $\S 1^{\circ}$. Disponível

<http://www.stf.jus.br/arquivo/cms/legislacaoRegimentoInterno/anexo/RISTF_integral.pdf $>$. Acesso em: 21 nov. 2018.

${ }^{26}$ BRASIL. Regimento Interno. Supremo Tribunal Federal. Brasília, 2018, Art. 231. Disponível em: 〈http://www.stf.jus.br/arquivo/cms/legislacaoRegimentoInterno/anexo/RISTF_integral.pdf>. Acesso em: 21 nov. 2018. 
escreveu: "O Tribunal estadual, alinhado à jurisprudência deste Sodalício [STJ], concluiu que o ato de indiciamento de detentores de foro especial é privativo de autoridade policial, sendo desnecessária para tal fim a autorização prévia do juízo competente. "27

Encerrada a fase preparatória com o oferecimento da denúncia, inicia-se a fase postulatória, que abrange desde a propositura da ação e a resposta do réu até o recebimento, ou não, da denúncia pelo Tribunal. $\mathrm{O}$ Relator deverá examinar se está presente alguma causa de extinção de punibilidade e, não havendo,determinará a notificação do acusado para oferecer sua resposta, que se traduz em uma defesa prévia, no prazo de 15 $\operatorname{dias}^{28}$.

Findo os prazos o Relator pedirá que o Tribunal delibere entre o recebimento e rejeição da denúncia ou queixa, ou improcedência da acusação, se a decisão não depender de outras $\operatorname{provas}^{29}$, nos dizeres de Plínio de Oliveira Corrêa, numa espécie de julgamento antecipado ${ }^{30}$. Recebida a denúncia o réu deverá ser interrogado, que dará início à fase probatória.

Esta nova fase obedecerá ao procedimento comum do Código de Processo Penal ${ }^{31}$. O interrogatório poderá ser realizado pelo próprio Relator ou, sob sua delegação, por juiz ou membro de tribunal com competência territorial para o cumprimento da carta de ordem.

Concluída a instrução do processo, com juntada de documentos, interrogatórios, acareações, inquirições de testemunhas, perícias e demais diligências necessárias, a acusação e a defesa deverão apresentar as alegações finais, encerrando a fase probatória.

Com o fim da fase decisória abre-se o prazo para a interposição de recursos. Mesmo diante do maior preparo das instâncias superiores, os julgadores não são infalíveis e, sendo consagrado o direito à ampla defesa, não se pode tolir essa prerrogativa nas ações penais originárias.

\footnotetext{
${ }^{27}$ BRASIL. Supremo Tribunal de Justiça. Agravo Habeas corpus n. ${ }^{\circ} 404.228$, da 5. ${ }^{\text {a }}$ Turma do Superior Tribunal de Justiça, Brasília, DF, $1^{\circ}$ de março de 2018 . Disponível em:〈http://www.mpf.mp.br/pgr/documentos/HC404228AcrdoSTJ.pdf >. Acesso em: 21 nov. 2018.

28 BRASIL. Lei n. ${ }^{\circ}$ 8038/90, de 28 de maio de 1990.art. 4. ${ }^{\circ}$. Brasília, Disponível em: <http://www.planalto.gov.br/ccivil_03/LEIS/L8038.htm>.Acesso em: $11 \mathrm{dez} .2018$.

29 BRASIL. Lei n. ${ }^{\circ}$ 8038/90, de 28 de maio de 1990. art. 6. ${ }^{\circ}$ Brasília, Disponível em: <http://www.planalto.gov.br/ccivil_03/LEIS/L8038.htm>.Acesso em: $11 \mathrm{dez} .2018$.

${ }^{30}$ CORRÊA, Plínio. Ação penal originária: Procedimentos. Porto Alegre: Síntese, 2001. p. 66.

31 BRASIL. Lei n. ${ }^{\circ}$ 8038/90, de 28 de maio de 1990, art. $9^{\circ}$. Brasília, Disponível em: <http://www.planalto.gov.br/ccivil_03/LEIS/L8038.htm>.Acesso em: 12 dez. 2018.
} 
Perante tal cenário é de se admitir que aqueles que detêm o foro especial possuem opções mais limitadas de recursos. Todavia, o grande debate reside no princípio do duplo grau de jurisdição, que se exerce através dos recursos, e as autoridades com ação penal originária no Supremo Tribunal Federal e no Superior Tribunal de Justiça, pois, tratando-se daquelas que são julgadas pelos tribunais de segunda instância, a possibilidade de recurso que reforme totalmente a decisão originária está presente.

O Supremo Tribunal Federal já se manifestou na questão afirmando que não há inconstitucionalidade, uma vez que: "o duplo grau de jurisdição, no âmbito da recorribilidade ordinária, não consubstancia garantia constitucional" 32 .

Deste modo, dá-se início à fase que se destina a proclamação da decisão do tribunal, todavia poderá ser convertido o julgamento em novas diligências, se assim entender necessário.

Procedendo o tribunal com o julgamento, na forma que determinar eu regimento interno, serão realizados os debates orais e, encerrada a votação do colegiado, proclamada a decisão, encerrado a fase.

No que se refere à execução, as leis processuais e constitucionais brasileiras, em diversos dispositivos, consagram a autorização à execução apenas após o trânsito em julgado da sentença penal condenatória, ou seja, após o momento em que não é mais possível interpor recursos, seja pelo decurso do prazo para recorrer ou pelo esgotamento das opções recursais.

Todavia, o Supremo Tribunal Federal, no julgamento do habeas corpus $\mathrm{n}^{\circ}{ }^{\circ} 126.292 / \mathrm{SP}^{33}$, alterou a orientação jurisprudencial permitindo a prisão após o julgamento em segunda instância, isto é, antes do trânsito em julgado. Uma das justificativas para esta relativização da presunção de inocência é a de que após o julgamento do tribunal haveria uma confirmação ou até uma ratificação da decisão, por uma corte superior; entretanto, cumpre entender como este entendimento afeta o julgamento dos detentores de foro especial.

\footnotetext{
${ }^{32}$ BRASIL. Supremo Tribunal Federal. Agravo Reg. em Agravos de Instrumento n. ${ }^{\circ}$ s 209.954-1/SP e 210.048-0/SP, Segunda Turma do Supremo Tribunal Federal. Relator Ministro Marco Aurélio, Diárioda justiça, Seção 1, 4 de dezembro de 1998.apud MORAES, Alexandre de. Direito constitucional. 12. ed. São Paulo: Atlas, 2002. p. 105.

${ }^{33}$ BRASIL. Supremo Tribunal Federal. Habeas Corpus n. ${ }^{\circ}$ 126.292/SP. Relator Ministro Teori Zavascki. Brasília, 17 de fevereiro de 2016.
} 
No habeas corpus $\mathrm{n}^{\circ}{ }^{\circ} 140.213 / \mathrm{SP}^{34}$, impetrado preventivamente pela defesa de um juiz condenado originariamente pelo Tribunal de Justiça de São Paulo, por exigir vantagem indevida em razão da função, o Supremo Tribunal Federal, após manifestação favorável do Ministério Público, decidiu que o fato do réu ter sido condenado em ação penal originária não escapa ao entendimento adotado pela corte.

\section{MODIFICAÇÕES PROVOCADAS NA QUESTÃO DE ORDEM DA AÇÃO PENAL 937}

Durante o curso da Ação Penal n. ${ }^{\circ} 937^{35}$, que tramita perante o Supremo Tribunal Federal, foi levantada questão de ordem para discutir sobre temas de grande relevância que geraram impactantes mudanças no foro especial.

O caso em discussão se refere à acusação de corrupção eleitoral de Marcos da Rocha Mendes durante sua campanha para a prefeitura de Cabo Frio/RJ em 2008. Com sua vitória nas urnas a competência para julgá-lo passou a ser do Tribunal Regional Eleitoral do Rio de Janeiro. Todavia, seu mandato se encerrou sem que o caso chegasse ao fim e seu processo foi remetido à primeira instância da Justiça Eleitoral.

Em 2015, como suplente, após afastamento dos titulares, assumiu a cadeira na Câmara dos Deputados, passando, portanto, a ter foro perante o Supremo Tribunal Federal, renunciando ao mandato em 2016 para assumir novamente a prefeitura de Cabo Frio, devendo novamente o caso ser remetido à segunda instância.

Entretanto, a Ação Penal já estava pronta para ser julgada pelo Supremo e diante da possibilidade de prescrição o relator, Ministro Luís Roberto Barroso, levantou questão de ordem abrindo duas importantes discussões.

A primeira se o foro por prerrogativa deve englobar tão somente as acusações por crimes relacionados ao desempenho da função escudada e enquanto o réu estiver o exercendo.

\footnotetext{
${ }^{34}$ BRASIL. Supremo Tribunal Federal. Habeas corpus n. ${ }^{\circ}$ 140.213/SP. Relator: Ministro Luiz Fux. Brasília, 20 de março de 2017.

${ }^{35}$ BRASIL. Supremo Tribunal Federal. Ação penal n. ${ }^{\circ}$ 937, Questão de Ordem. Relator: Ministro Luis Roberto Barroso. Brasília, Disponível em: <https://portal.stf.jus.br/processos/detalhe.asp?incidente=4776682>. Acesso em: 05 mar. 2019.
} 
A segunda é se a jurisdição do STF deve se perpetuar após a cessação do mandato nas hipóteses em que já ocorreu a instrução processual.

No julgamento, prevaleceu a tese elaborada pelo Ministro Luís Roberto Barroso definindo que:

(i) $\mathrm{O}$ foro por prerrogativa de função aplica-se apenas aos crimes cometidos durante o exercício do cargo e relacionados às funções desempenhadas; e

(ii) Após o final da instrução processual, com a publicação do despacho de intimação para apresentação de alegações finais, a competência para processar e julgar ações penais não será mais afetada em razão de o agente público vir a ocupar outro cargo ou deixar o cargo que ocupava, qualquer que seja o motivo. ${ }^{36}$

Deste modo, firmou-se o entendimento de restringir o foro, que antes alcançava todos os crimes das funções prevista no art. 102, inciso I, alínea $b$ e $c$, da Constituição, para apenas os crimes cometidos no exercício do cargo e em razão deste. Ficando excluídos os crimes praticados antes da investidura e os desconexos com seu exercício.

Quanto ao momento da fixação definitiva da competência, tendo em vista a possibilidade de prorrogação de competência constitucional para preservar a efetividade da tutela jurisdicional, ficou-se decidido que a partir do final da instrução processual, com a publicação do despacho de intimação para apresentar alegações finais, a competência do STF ou de qualquer outro órgão, não será mais alterada.

Como o caso concreto referia-se a um parlamentar, a corte decidiu dar o entendimento supracitado apenas aos parlamentares abarcados na competência do Supremo Tribunal Federal, ou seja, aos Deputados Federais e Senadores. O Ministro Dias Toffoli apresentou ainda uma tese para abarcar todas as autoridades detentoras de foro especial, dando esta interpretação inclusive às constituições estaduais; todavia, foi voto vencido.

O Supremo Tribunal se adiantou ao Congresso que já vinha sinalização que votaria uma mudança no foro privilegiado, no que muitos chamariam de usurpação do poder legislativo, uma vez que a lei é clara ao

\footnotetext{
${ }^{36}$ BRASIL. Supremo Tribunal Federal. Ação Penal n. ${ }^{\circ}$ 937, Questão de Ordem. Relator Ministro Luis Roberto Barroso. Brasília, Disponível em: <https://portal.stf.jus.br/processos/detalhe.asp?incidente=4776682>. Acesso em: 05 mar. 2019.
} 
dizer que a prerrogativa é para os crimes comuns, não havendo limitações materiais e temporais.

Todavia, o julgamento no sentido de restringir o foro especial foi dado pela Corte através de um entendimento de que sua até então aplicação violava os princípios da igualdade e da república e, por terem sido incluídos deputados e senadores, conforme já relatado, apenas durante o Regime Militar, haveria uma necessidade de se harmonizar o foro privilegiado com o restante da Constituição de 1988.

O entendimento, como altera a interpretação do art. 102 da Constituição, não se aplica as autoridades que tenham a prerrogativa de foro perante outros tribunais ou as funções que não sejam deputados federais e senadores e tenham a prerrogativa perante o STF. Todavia, outros Tribunais já estão aplicando o entendimento através do princípio da simetria constitucional.

Ainda, a interpretação foi dada com o efeito ex nunc, sendo aplicada nos processos em cursos, mas preservados os atos e decisões proferidas pelo Supremo e demais juízos embasados na jurisprudência anterior.

Cumpre também revelar que o STF declina a competência ou deixa prescrever $65 \%$ das ações penais, segundo o V Relatório Supremo em Números ${ }^{37}$; isto significa que em praticamente dois de cada três casos este Tribunal não chega nem mesmo a analisar e emitir juízo sobre o mérito da questão, ou porque demora demais e perde a pretensão punitiva ou porque delonga a tal ponto que o sujeito perde a prerrogativa perante este órgão.

Corroborando com este dado, apenas 5,94\% das ações que tiveram seu inquérito no Supremo foram lá finalizadas ${ }^{38}$, ou seja, nas outras 94,06\% das ações cujo inquérito foi iniciado pelo STF, ou houve prescrição, ou mudança na competência.

Tendo em vista isso, faz-se necessário especular os motivos de tamanha morosidade, sendo apontado pelos próprios ministros o grande número de ações penais de competência originária tramitando perante a

\footnotetext{
${ }^{37}$ FALCÃO, Joaquim et al. V Relatório Supremo em Números: o foro privilegiado. Rio de Janeiro: Escola de Direito do Rio de Janeiro da Fundação Getúlio Vargas, 2017. p. 82.

${ }^{38}$ FALCÃO, Joaquim et al. V Relatório Supremo em Números: o foro privilegiado. Rio de Janeiro: Escola de Direito do Rio de Janeiro da Fundação Getúlio Vargas, 2017. p. 9.
} 
corte $^{39}$. A mudança realizada na questão de ordem da Ação Penal 937 ataca justamente este ponto.

Isto pois, apenas $5,44 \%$ das ações penais que tramitam perante $o$ Supremo Tribunal Federal envolvem crimes que tenham sido cometidos em razão do cargo e durante o exercício do mandato ${ }^{40}$. Ou seja, com a alteração, a corte está retirando de sua competência mais de $94 \%$ das ações penais que possui. Assim, há que assumir o profundo impacto que tal interpretação gerará no Órgão Julgador, provavelmente afetando muito a eficácia da corte nas ações penais que restaram.

Entretanto, fica evidente a existência de um ativismo judicial no presente caso, pois a Constituição não faz distinção dos crimes que serão abarcados pelo foro, pois a intenção do legislador foi justamente abranger todos.

Neste sentido, é necessário se atentar para a insegurança jurídica que pode ser causada por decisões advindas do ativismo, pois basta comparar a dificuldade de se fazer a mudança realizada na AP 937 através das vias regulares. Seria preciso uma Proposta de Emenda à Constituição, que deveria ser aprovada com três quintos dos votos, da totalidade dos membros da casa, em dois turnos de votação, na Câmara e no Senado. Tal alteração foi realizada pelo Supremo, durante o julgamento de um caso concreto, com quórum de 7 votos favoráveis e 4 contrários à mudança. É gritante e preocupante a facilidade da Corte de alterar completamente as redações legislativas.

Sendo a constante mudança de competência um dos maiores gargalos do andamento processual do foro especial, ponto diretamente combatido com o segundo item definido no julgamento que alterou a prerrogativa, é preciso evidenciar a instabilidade da decisão, sujeita a reformas da própria corte ou do legislativo, que podem acarretar em novas alterações de instância, que prejudicará ainda mais o julgamento dos processos.

\section{REFERÊNCIAS}

\footnotetext{
${ }^{39}$ FALCÃO, Joaquim et al. V Relatório Supremo em Números: o foro privilegiado. Rio de Janeiro: Escola de Direito do Rio de Janeiro da Fundação Getúlio Vargas, 2017. p. 22 e 81.

${ }^{40}$ FALCÃO, Joaquim et al.V Relatório Supremo em Números: o foro privilegiado. Rio de Janeiro: Escola de Direito do Rio de Janeiro da Fundação Getúlio Vargas, 2017. p. 80.
} 
BRASIL. Ato Institucional n. ${ }^{\circ}$ 5, de 13 de novembro de 1968. Disponível em: <http://www.planalto.gov.br/ccivil_03/AIT/ait-05-68.htm>. Acesso em: 02 ago. 2019. Secção 1 .

Colecção de Leis do Império do Brasil. Rio de Janeiro, 1851. Tomo 12. Parte 1.

.Constituição (1824). Constituição Política do Império do Brazil. Outorgada em 25 de março de 1824. Disponível em:

<http://www.planalto.gov.br/ccivil_03/Constituicao/Constituicao24.htm>. Acesso em: 02 ago. 2019.

.Constituição (1891). Constituição da República dos Estados Unidos do Brasil. Promulgada em 24 de fevereiro de 1891. Disponível em:

<http://www.planalto.gov.br/ccivil_03/Constituicao /Constituicao91.htm>. Acesso em: 02 ago. 2019.

.Constituição (1934). Constituição da República dos Estados Unidos do Brasil. Promulgada em 16 de julho de 1934. Art. 76, 1º, alínea A e B. Disponível em: <http://www.planalto.gov.br/ccivil_03/Constituicao/Constituicao34.htm>. Acesso em: 02 ago. 2019.

.Constituição (1937). Constituição dos Estados Unidos do Brasil. Outorgada pelo Presidente Getúlio Vargas em 10 de novembro de 1937. Art. 87. Disponível em: <http://www.planalto.gov.br/ccivil_03/Constituicao/Constituicao37.htm>. Acesso em: 02 ago. 2019.

.Constituição (1946). Constituição dos Estados Unidos do Brasil. Promulgada em 18 de setembro de 1946. Art. 88. Disponível em: <http://www.planalto.gov.br/ccivil_03/Constituicao/Constituicao46.htm>. Acesso em: 02 ago. 2019.

.Constituição (1967). Constituição da República Federativa do Brasil. Promulgada em 24 de janeiro de 1967. Disponível em: <http://www.planalto.gov.br/ccivil_03/Constituicao/Constituicao67.htm>. Acesso em: 02 ago. 2019.

.Lei n. ${ }^{\circ}$ 8038/90, de 28 de maio de 1990. Brasília, Disponível em:

<http://www.planalto.gov.br/ccivil_03/LEIS/L8038.htm>. Acesso em: 04 ago. 2019.

.Regimento Interno. Supremo Tribunal Federal. Brasília, 2018. Disponível em: <http://www.stf.jus.br/arquivo/cms/legislacaoRegimentoInterno/anexo/RISTF_integral.pd f>. Acesso em: 04 ago. 2019.

.Supremo Tribunal Federal. Ação penal n. ${ }^{\mathbf{9 3}}$, Questão de Ordem. Relator: Ministro Luis Roberto Barroso. Brasília, Disponível em: 
$<$ https://portal.stf.jus.br/processos/detalhe.asp?incidente=4776682>. Acesso em: 08 ago. 2019.

.Supremo Tribunal de Justiça. Agravo Habeas corpus n. ${ }^{\circ} 404.228$, da 5. ${ }^{\text {a }}$ Turma do Superior Tribunal de Justiça, Brasília, DF, $1^{\circ}$ de março de 2018. Disponível em: <http://www.mpf.mp.br/pgr/documentos/HC404228AcrdoSTJ.pdf >. Acesso em: 04 ago. 2019.

Supremo Tribunal Federal. Agravo Reg. em Agravos de Instrumento n. ${ }^{\circ} \mathrm{s}$ 209.954-1/SP e 210.048-0/SP, Segunda Turma do Supremo Tribunal Federal. Relator Ministro Marco Aurélio, Diárioda justiça, Seção 1, 4 de dezembro de 1998.apud MORAES, Alexandre de. Direito constitucional. 12. ed. São Paulo: Atlas, 2002.

.Supremo Tribunal Federal. Habeas Corpus n. ${ }^{\circ}$ 126.292/SP. Relator Ministro Teori Zavascki. Brasília, 17 de fevereiro de 2016.

Supremo Tribunal Federal. Habeas corpus n. $^{\circ}$ 140.213/SP. Relator: Ministro Luiz Fux. Brasília, 20 de março de 2017.

CAVAlCANTE FILHO, J. T. \& LIMA, F. R. Foro, Prerrogativa e Privilégio (Parte 1): Quais e quantas autoridades têm foro no Brasil? Brasília: Núcleo de Estudos e Pesquisas/ CONLEG/Senado, 2017.

CORRÊA, Plínio. Ação penal originária: Procedimentos. Porto Alegre: Síntese, 2001.

FALCÃO, Joaquim et al. V Relatório Supremo em Números: o foro privilegiado. Rio de Janeiro: Escola de Direito do Rio de Janeiro da Fundação Getúlio Vargas, 2017.

MELLO, Fernando Collor de. Réplica para a história: uma catarse. Brasília: Senado Federal, 2016.. Disponível em:

<http://www2.senado.leg.br/bdsf/bitstream/handle/id/526360/Replica_Impeachment.pd f? sequence=1>. Acesso em: 02 ago. 2019.

PONTES DE MIRANDA, Francisco Cavalcanti. Comentários à Constituição de 1967. São Paulo: Revista dos Tribunais, 1968. 